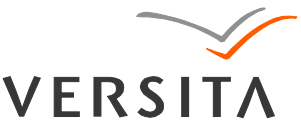

GEOCHRONOMETRIA 40(2) 2013: 134-144

DOI 10.2478/s13386-013-0106-9

Available online at

www.springerlink.com

\title{
U-Pb ZIRCON AGE OF THE YOUNGEST MAGMATIC ACTIVITY IN THE HIGH TATRA GRANITES (CENTRAL WESTERN CARPATHIANS)
}

\author{
JOLANTA BURDA ${ }^{\mathbf{1}}$, ALEKSANDRA GAWEDA ${ }^{\mathbf{1}}$ and URS KLÖTZLI ${ }^{\mathbf{2}}$ \\ ${ }^{I}$ Faculty of Earth Sciences, University of Silesia, Będzińska 60, 41-200 Sosnowiec, Poland \\ ${ }^{2}$ Department of Lithospheric Research, University of Vienna, Althanstrasse 14, 1090 Vienna, Austria
}

Received 13 November 2013

Accepted 18 February 2013

\begin{abstract}
Detailed cathodoluminescence (CL) imaging of zircon crystals, coupled with Laser Ablation Multi-Collector Inductively Coupled Plasma Mass Spectrometry (LA-MC-ICP-MS) U-Pb zircon dating was used to develop new insights into the evolution of granitoids from the High Tatra Mountains. The zircon U-Pb results show two distinct age groups ( $350 \pm 5 \mathrm{Ma}$ and $337 \pm 6 \mathrm{Ma}$ ) recorded from cores and rims domains, respectively. Obtained results point that the last magmatic activity in the Tatra granitoid intrusion occurred at ca. $330 \mathrm{Ma}$. The previously suggested age of $314 \mathrm{Ma}$ reflects rather the hydrothermal activity and $\mathrm{Pb}$-loss, coupled with post-magmatic shearing.
\end{abstract}

Keywords: Central Western Carpathians, High Tatra granite, U-Pb zircon age.

\section{INTRODUCTION}

The Tatra Mountains crystalline core forms an uplifted portion of a Variscan crust, tectonically emplaced into the Alpine mountain chain of the Central Western Carpathians (Fig. 1a). The crystalline basement of the Tatra Mountains comprises a volumetrically predominant Variscan granitoid intrusion and its metamorphic envelope, extensively migmatized during the time span of 367-358 Ma (Fig. 1a; Burda, 2006 and Burda and Gawęda, 2009).

Polygenetic granitoid pluton comprises four petrographical types of granitoids (Morozewicz, 1914 and Kohút and Janak, 1994). The common Tatra granodioritetonalite forms a volumetrically predominant tongueshaped intrusion, dated at 368-350 Ma (Poller et al., 2000 and Burda et al., 2011). Quartz-diorites (I-type mingled hybrid, interpreted as magmatic precursors) are present as sills inside the metamorphic envelope and in the border zone of the common Tatra granite (Gawęda et al., 2005).

Corresponding author: J. Burda e-mail: jolanta.burda@us.edu.pl
The mingling-mixing processes between the common Tatra type and quartz-diorite precursors were dated at $368 \pm 8$ Ma (Burda et al., 2011). Goryczkowa-type granites (I and S-type), characterised by oriented fabric, were distinguished in the northern part of the crystalline core (Fig. 1a) and dated at $356 \pm 8 \mathrm{Ma}$ (Burda and Klötzli, 2007). The High Tatra granite (I/S-type) occurs in the eastern part of the massif and is characterised by an abundance of mafic enclaves and xenoliths of country rocks (Gawęda, 2009). The High Tatra granite originated most likely by partial melting of recycled Proterozoic crustal rocks, with the simultaneous input of mafic magmas from the mantle. The mafic magma portions are thought to be the heat source for melting of the continental crust (Broska and Uher, 2001 and Kohút and Nabelek, 2008). The age of that granite body is still controversial. Whole Rock (WR) Rb-Sr dating by Burchart (1970) suggested an age of ca. 300 Ma for the Tatra granitoid intrusion. ${ }^{40} \mathrm{Ar} /{ }^{39} \mathrm{Ar}$ laser probe dating of biotite (Janak, 1994) suggest the wide spectrum of cooling ages around 300$330 \mathrm{Ma}$ for the Tatra granitoid intrusion, supported later 


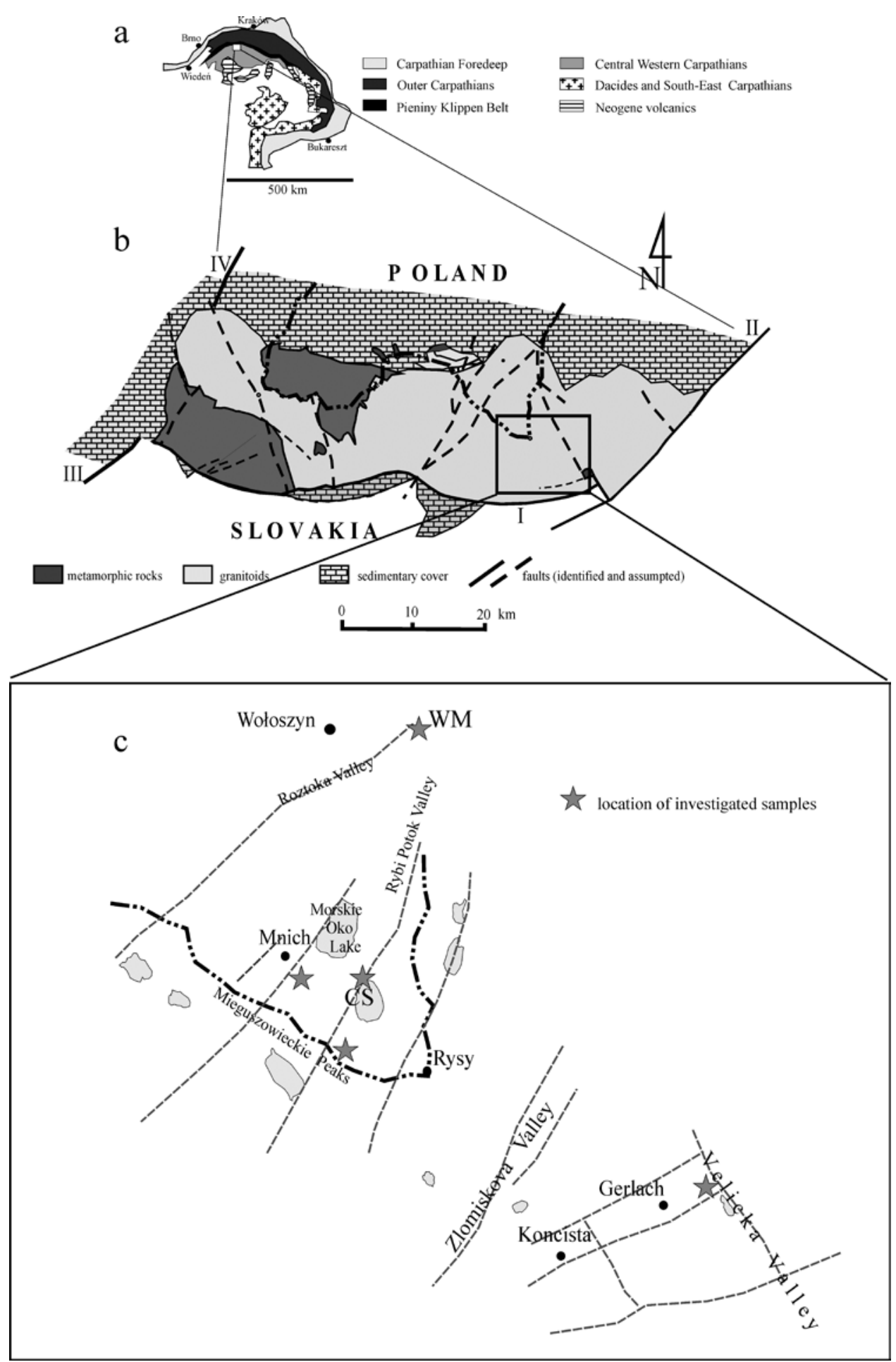

Fig. 1. The geology of the Tatra Mountains. a - simplified geological sketch of the Carpathian chain; $b$ - geological map of the Tatra Mountains Block; c - draft of the study area with sample locations. 
by Kohut and Sherlock (2003). The published U-Pb zircon dating located the youngest age of magmatic activity in the High Tatra granites at $314 \mathrm{Ma}$ on the base of U-Pb lower intercept age (Poller et al., 2000; Poller and Todt, 2000). The same authors obtained partial melting and migmatization $\mathrm{U}-\mathrm{Pb}$ zircon age at $335 \mathrm{Ma}$, which is $c a$. 30 Ma younger than the migmatization and partial melting age obtained for the metamorphic complex of the Western Tatra Mountains (367-358 Ma; Burda and Gawęda, 2009).

However, $\mathrm{U}-\mathrm{Pb}$ zircon dating of a magmatic enclave from the High Tatra granite pointed out the youngest magmatic episode at $345 \mathrm{Ma}$ while $\mathrm{WR} \mathrm{Rb-Sr}$ data for the same rock samples allowed interpreting the age interval 312-315 Ma as shearing episode during cooling (Gawęda, 2008). Burda (2010) interpreted the $335 \mathrm{Ma}$ concordia age of the zircon crystals from the High Tatra Mountains as the youngest magmatic episode in that area.

The aim of this paper is to solve the basic geochronological question about the time frames of the magmatic activity in the High Tatra Mountains and the real meaning of the 315-312 Ma ages. For this purpose we use the LAMC-ICP-MS (Laser Ablation Multi-Collector Inductively Coupled Plasma Mass Spectrometry) U-Pb zircon dating, coupled with detailed cathodoluminescence (CL) imaging and whole-rock chemistry, to develop new insights into the evolution of granitoids from the High Tatra Mountains.

\section{SAMPLING AND ANALYTICAL TECHNIQUES}

According to Kohút and Janak (1994) the High Tatra granite covered the area roughly triangular in shape, from Rysy (N) to Slavkovska Valley to SE and Osterwa to SW. Recent geological mapping enlarges that area further to the north in Poland, to Mięguszowieckie Peaks and further to Kozie Peaks in NW (Gawęda, 2009). This area is currently interpreted as the mixing-mingling zone, additionally complicated by the presence of numerous xenoliths (Gawęda, 2009 and Gawęda and Szopa, 2011).

Five representative samples of granitoids from the High Tatra Mountains, weighting about $25 \mathrm{~kg}$, were collected with permission from the Polish Ministry of Environment and the Tatra National Park. Mineral analyses were carried out in the Inter-Institution Laboratory of Microanalyses of Minerals and Synthetic Substances, Warsaw (CAMECA SX-100 electron microprobe; $15 \mathrm{kV}$, $20 \mathrm{nA})$.

Whole-rock samples were analysed by ICP-ES (Inductively Coupled Plasma Emission Spectrometer) for major and LILE (large-ion lithophile) elements and by ICP-MS (Inductively Coupled Plasma Mass Spectrometry) for HFSE (high field strength elements) and REE in the ACME Analytical Laboratories, Vancouver, Canada, using sets of internationally recognized standards, according to procedures described on http://acmelab.com. REEs are normalized to $\mathrm{C} 1$ chondrite (Sun and McDonough, 1989).
Zircon crystals were separated using standard techniques (crushing, hydrofracturing, washing, Wilfley shaking table, Frantz magnetic separator and handpicking). The separation was carried out at the Institute of Geological Sciences, Polish Academy of Sciences, Cracow.

From two representative samples (CS and WM; Fig. 1b) 160 zircon crystals, classified by their translucence and grain size were hand-picked and mounted. Zircon grains were selected for morphological study using scanning electron microscopy and then imaged by panchromatic cathodoluminescence on a FET Philips 30 electron microscope $(15 \mathrm{kV}$ and $1 \mathrm{nA})$ at the Faculty of Earth Sciences, University of Silesia, Sosnowiec, Poland. Cathodoluminescence $(\mathrm{CL})$ pictures of the zircon grains revealed information about internal structures of the zircons.

Zircon ${ }^{206} \mathrm{~Pb} /{ }^{238} \mathrm{U}$ and ${ }^{207} \mathrm{~Pb} /{ }^{206} \mathrm{~Pb}$ ages were determined using a $193 \mathrm{~nm}$ solid state Nd-YAG (a neodymium-doped yttrium aluminium garnet is used as the laser medium) laser (NewWave UP193-SS) coupled with a multi-collector ICP-MS (Nu Instruments HR) at the University of Vienna (Austria). Ablation in a He atmosphere was raster-wise according to the CL zoning pattern of the zircons. Line widths for the raster were $10-15 \mu \mathrm{m}$ with a raster speed of $5 \mu \mathrm{m} / \mathrm{sec}$. Energy densities were $5-8 \mathrm{~J} / \mathrm{cm}^{2}$ with a repetition rate of $10 \mathrm{~Hz}$. Helium carrier gas was mixed with the Ar carrier gas flow prior to the plasma torch. Ablation duration was 60 to $120 \mathrm{~s}$ with a $30 \mathrm{~s}$ gas and $\mathrm{Hg}$ blank count rate measurement preceding ablation. Ablation count rates were corrected accordingly offline. Remaining counts on mass 204 were interpreted as representing ${ }^{204} \mathrm{~Pb}$. Static mass spectrometer analysis was as follows: ${ }^{238} \mathrm{U}$ in a Faraday detector, ${ }^{207} \mathrm{~Pb},{ }^{206} \mathrm{~Pb}$, and ${ }^{204}(\mathrm{~Pb}+\mathrm{Hg})$ in ion counter detectors. ${ }^{208} \mathrm{~Pb}$ was not analyzed. An integration time of $1 \mathrm{~s}$ was used for all measurements. The ion counter - Faraday and inter-ion counter gain factors were determined before the analytical session using zircon standards: 91500 (Wiedenbeck et al., 1995) and Plesovice (Slama et al., 2006). Sensitivity for ${ }^{206} \mathrm{~Pb}$ on standard zircon 91500 was ca. $30000 \mathrm{cps}$ per ppm Pb. For ${ }^{238} \mathrm{U}$ the corresponding value was ca. 35000 . Mass and elemental bias and mass spectrometer drift of both $\mathrm{U} / \mathrm{Pb}$ and $\mathrm{Pb} / \mathrm{Pb}$ ratios respectively, were corrected using a multi-step approach: first-order mass bias was corrected using a dried ${ }^{233} \mathrm{U}^{205} \mathrm{Tl}-{ }^{203} \mathrm{Tl}$ spike solution which was aspirated continuously in $\mathrm{Ar}$ and mixed to the He carrier gas coming from the laser before entering the plasma. This corrects for bias effects stemming from the mass spectrometer. The strongly time-dependent elemental fractionation coming from the ablation process itself was then corrected using the "intercept method" of Sylvester and Ghaderi (1997). The calculated ${ }^{206} \mathrm{~Pb} /{ }^{238} \mathrm{U}$ and ${ }^{207} \mathrm{~Pb} /{ }^{206} \mathrm{~Pb}$ intercept values were corrected for mass discrimination from analyses of standards 91500 and Plesovice, measured during the analytical session using the standard bracketing method. The correction utilizes regression of standard measurements by a quadratic func- 
tion. A common $\mathrm{Pb}$ correction was applied to the final data using the apparent ${ }^{207} \mathrm{~Pb} /{ }^{206} \mathrm{~Pb}$ age and the StaceyKramers Pb evolution model (Stacey and Kramers, 1975). Final age calculation was made with "Isoplot/Ex 3.00" (Ludwig, 2003).

\section{RESULTS}

\section{Whole-rock chemistry}

The analysed granitoids are rich in silica $\left(\mathrm{SiO}_{2}=\right.$ 66-72\%), weakly peraluminous in composition (ASI = 1.09-1.27), low in $\mathrm{Rb}(\mathrm{Rb} / \mathrm{Sr}=0.05-0.19$; Table 1$)$. The \#mg number is quite constant $(0.54-0.56$, while $\mathrm{Zr}$ content varies in the range of 91.6-150.9 ppm, which implies the calculated temperatures according to Watson and Harrison (1983) procedure to be in the range of $748-800^{\circ} \mathrm{C}$ (Table 1). Total REE content ranges from 106.15 to $204.04 \mathrm{ppm}$. REEs are weakly to moderately fractionated $\left(\mathrm{Ce}_{\mathrm{N}} / \mathrm{Yb}_{\mathrm{N}}=9.83-23.56\right)$ and show negative Eu anomalies $\left(\mathrm{Eu} / \mathrm{Eu}^{*}=0.636-0.896\right.$; Table 1).

\section{Petrography and mineral chemistry}

The collected granitoids are medium- to coarse-grained monzogranites (Fig. 2a, b), composed of zoned plagioclase (oligoclase-andesine $\mathrm{An}_{14-24}$ ), showing sharp compositional discontinuities ("calcic spikes") and cores in the range $\mathrm{An}_{35-50}$, perthitic alkali feldspars with reconstructed bulk composition in the range of $\mathrm{Or}_{86} \mathrm{Ab}_{11} \mathrm{An}_{1} \mathrm{Cn}_{2}$ $\mathrm{Or}_{78} \mathrm{Ab}_{15} \mathrm{An}_{3} \mathrm{Cn}_{4}$; Gawęda and Sikorska, 2009 and Gawęda and Szopa, 2011), quartz, biotite $(\boldsymbol{f m}=0.541-0.587)$, muscovite (both magmatic and post-magmatic ones). $\mathrm{Mg}$ hornblende occurs in rock-portions showing mixingmingling features (Gawęda and Szopa, 2011).
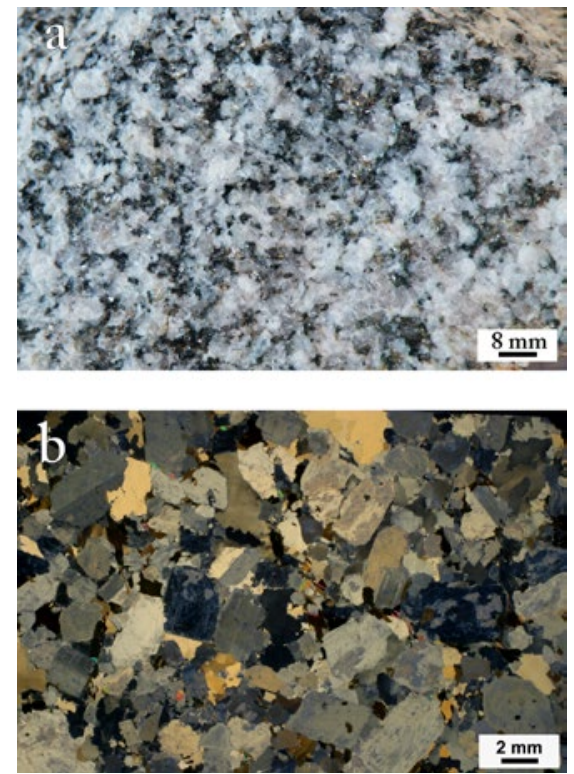

Fig. 2. Representative photograph (a) and microphotograph (b) of the High Tatra granitoids (crossed nicols).
Locally the porphyritic varieties of granitoids are characterised by the presence of alkali feldspar megacrysts with rapakivi-like overgrowths. These megacrysts show oscillatory chemical zonation, expressed as changes in the barium content, underlined by the rows of inclusions (plagioclase, quartz, biotite, magnetite-ilmenite). Accessory minerals are apatite, monazite-(Ce), xenotime, zircon, composite exsolved Ti-magnetite-ilmenite grains (after ulvospinel) and hematite (Grabowski and Gawęda, 1999). Both ternary feldspar and ilmenite-magnetite geothermometric calculations pointed out temperatures of

Table 1. Chemical composition of the representative samples of High Tatra granitoids. Major elements in mass \%, trace elements in ppm; A/CNK - molar Al2O3/(CaO + Na2O + K2O); LOI - loss on ignition; $E u / E u^{*}=E u / \sqrt{ } S m x G d$

\begin{tabular}{|c|c|c|c|c|c|}
\hline Sample & CS & WM & Mn4 & Kmieg1 & DV3/3 \\
\hline $\mathrm{SiO}_{2}$ & 66.21 & 68.58 & 71.12 & 69.82 & 72.05 \\
\hline $\mathrm{TiO}_{2}$ & 0.4 & 0.37 & 0.35 & 0.4 & 0.28 \\
\hline $\mathrm{Al}_{2} \mathrm{O}_{3}$ & 17.59 & 16.2 & 15.6 & 16.27 & 14.77 \\
\hline $\mathrm{Fe}_{2} \mathrm{O}_{3}$ & 3 & 2.92 & 2.22 & 2.64 & 2.07 \\
\hline $\mathrm{MnO}$ & 0.04 & 0.04 & 0.03 & 0.03 & 0.03 \\
\hline $\mathrm{MgO}$ & 0.91 & 0.89 & 0.67 & 0.83 & 0.68 \\
\hline $\mathrm{CaO}$ & 3.31 & 2.89 & 1.77 & 0.92 & 1.85 \\
\hline $\mathrm{Na}_{2} \mathrm{O}$ & 4.74 & 4.62 & 4.82 & 4.56 & 3.59 \\
\hline $\mathrm{K}_{2} \mathrm{O}$ & 2.48 & 1.75 & 2.38 & 3.66 & 3.7 \\
\hline $\mathrm{P}_{2} \mathrm{O}_{5}$ & 0.14 & 0.126 & 0.08 & 0.14 & 0.12 \\
\hline LOI & 1.0 & 1.4 & 1.2 & 0.9 & 1.0 \\
\hline Total & 99.82 & 99.82 & 100.24 & 100.17 & 100.14 \\
\hline $\mathrm{Sr}$ & 637.3 & 706 & 360 & 421.9 & 554.4 \\
\hline $\mathrm{Ba}$ & 778 & 730 & 558.9 & 975.7 & 1163.4 \\
\hline $\mathrm{Rb}$ & 64.2 & 38.9 & 51.1 & 78.8 & 76.8 \\
\hline Th & 18 & 6.7 & 8.3 & 9.6 & 7.8 \\
\hline U & 1.7 & 1.1 & 1.3 & 1.9 & 1.2 \\
\hline $\mathrm{Pb}$ & 6.1 & 3.1 & 7.7 & 14.7 & 9.4 \\
\hline $\mathrm{Ga}$ & 20.1 & 19 & 19.7 & 20.5 & 16.9 \\
\hline V & 44 & 39 & 34 & 35 & 30 \\
\hline $\mathrm{Zr}$ & 121.1 & 150.9 & 121.7 & 147.3 & 91.6 \\
\hline $\mathrm{Hf}$ & 3.4 & 4.5 & 3.4 & 4.2 & 3 \\
\hline Y & 15.6 & 6.2 & 17.6 & 13 & 8.2 \\
\hline $\mathrm{Nb}$ & 6.1 & 4.4 & 6.8 & 6.4 & 4.9 \\
\hline $\mathrm{Ta}$ & 0.3 & 0.2 & 0.1 & 0.4 & 0.5 \\
\hline $\mathrm{La}$ & 41.6 & 27.5 & 24.9 & 28.2 & 22.6 \\
\hline $\mathrm{Ce}$ & 89.8 & 59.2 & 51 & 60.7 & 46.4 \\
\hline $\mathrm{Pr}$ & 10.59 & 6.98 & 6.23 & 7.12 & 5.45 \\
\hline $\mathrm{Nd}$ & 40.2 & 25.9 & 23.3 & 26.5 & 19.7 \\
\hline Sm & 7.02 & 4.01 & 4.9 & 5.5 & 4.2 \\
\hline $\mathrm{Eu}$ & 1.47 & 0.98 & 0.89 & 1.02 & 0.92 \\
\hline $\mathrm{Gd}$ & 5.44 & 2.79 & 3.74 & 4.14 & 2.88 \\
\hline $\mathrm{Tb}$ & 0.63 & 0.3 & 0.56 & 0.54 & 0.37 \\
\hline Dy & 3.63 & 1.57 & 3.14 & 2.75 & 1.85 \\
\hline $\mathrm{Ho}$ & 0.62 & 0.26 & 0.55 & 0.43 & 0.29 \\
\hline $\mathrm{Er}$ & 1.61 & 0.7 & 1.58 & 1.13 & 0.65 \\
\hline $\mathrm{Tm}$ & 0.23 & 0.13 & 0.24 & 0.17 & 0.11 \\
\hline $\mathrm{Yb}$ & 1.05 & 0.72 & 1.43 & 0.79 & 0.64 \\
\hline ASI & 1.088 & 1.121 & 1.153 & 1.271 & 1.137 \\
\hline Lu & 0.15 & 0.12 & 0.18 & 0.12 & 0.09 \\
\hline total REE & 205.13 & 132.28 & 123.79 & 140.38 & 107.29 \\
\hline $\mathrm{Rb} / \mathrm{Sr}$ & 0.101 & 0.055 & 0.142 & 0.187 & 0.139 \\
\hline \#mg & 0.546 & 0.547 & 0.545 & 0.555 & 0.566 \\
\hline
\end{tabular}


crystallization in the range of $720-890^{\circ} \mathrm{C}$ and pressure at 4-6 kbar (Gawęda and Szopa, 2011). Epidote, Ca-garnet, chlorite, titanite, sericite, sporadically prehnite and Fepumpellyite are secondary minerals linked to lowtemperature post-magmatic alterations (Leichman et al., 2009 and Gawęda and Włodyka, 2013).

\section{Zircon dating}

\section{Wodogrzmoty Mickiewicza (WM) sample}

Zircon crystals from the sample WM are euhedral, clear, colourless, 50 to $250 \mu \mathrm{m}$ long, with aspect ratios $<$ 4:1. In most crystals the [110] prism is better developed than [100], with the dominating [101] bipyramid (Fig. 3). CL images revealed well-developed oscillatory zoning, ranging from fine to broad within individual grains. Some grains display a brighter interior that is enclosed by a darker rim. Because oscillatory zoning in internal domains is parallel to marginal rims, there are not considered to be inherited cores. The interface between these two domains is regular to irregular (Fig. 4).

Zircon analyses from sample WM plot in three groups corresponding to the associated structures observed in CL images (Fig. 4; Table 2). Nine analyses (group A) from the rims define the concordia age of $337 \pm 6$ (2 sigma). Seven analyses (group B) of the internal domains yield a concordia age of $350 \pm 5 \mathrm{Ma}$ (2 sigma; Fig. 5; Table 2). Four inherited cores give ages of ca. $450 \mathrm{Ma}, 516 \mathrm{Ma}$, $1500 \mathrm{Ma}$ and ca. $2350 \mathrm{Ma}$ (group C; Fig. 4; Table 2) .

\section{Czarny Staw (CS) sample}

Zircon crystals from the sample CS are euhedral, both long- and short-prismatic, ranging in length from 100 to

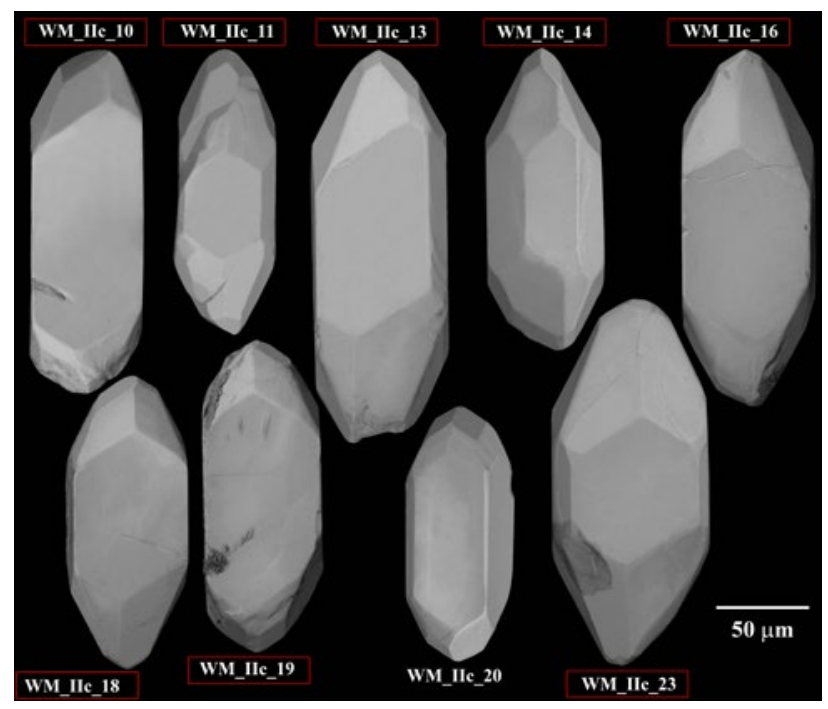

Fig. 3. Secondary electron (SEM) images of zircon crystals from sample WM.Most crystals show a predominance of [110] prism and the presence of two pyramids [101, 211]. For the marked crystals by boxes cathodoluminescence images are presented in the Fig. 4.
$300 \mu \mathrm{m}$, with aspect ratios of $1: 2$ to $1: 5$. In most crystals prisms [110] and [100] are similar and the [211] bipyramid dominates over the [101], what correspond with subtypes S2, S3 and S6 (Fig. 6; Pupin, 1980).

A small number of inherited cores were observed (Fig. 7). Variably developed oscillatory zoning is the prominent feature of all analysed grains, as shown by moderate to weak luminescence. In some grains growth zoning progressively less luminescent toward the margins is observed (Fig. 7). Sometimes grains display irregular, homogeneous patches with diffuse boundaries, which crosscut or obliterate growth-zoned domains, possibly related to subsolidus modification during late-magmatic stages (Fig. 7).

Zircon $\mathrm{U}-\mathrm{Pb}$ data from sample CS plot in two groups (Table 3). The first group of ages formed the outer rims (group A), showing oscillatory zoning, which define the concordia age of $345 \pm 6$ Ma (2 sigma; Fig. 8; Table 3 ).

The second group (group C) comprises the oscillatory zoned cores showing a large spread in concordant ages (394, 460, 506, 534 Ma; Table 3).

\section{DISCUSSION}

The geochemistry and mineral composition of the analysed granitoids suggest, that all the analysed samples represent magma batches of the same mineralogy, chemistry and origin. All applied geothermometers gave similar, relatively high temperature range for magma crystallization: $720-890^{\circ} \mathrm{C}$, supporting the suggested mafic magma influx (Kohút and Nabelek, 2008 and Gawęda, 2009).

In zircon crystals from sample WM two Variscan magmatic episodes are imprinted. The older episode recorded in the internal domains, dated at $350 \pm 5 \mathrm{Ma}$ (group B; Table 2; Fig. 4) could represent antecrysts, which crystallized from an earlier pulse of magma (Hildreth, 2004). The low-luminescence rims showing the younger age $337 \pm 6 \mathrm{Ma}$ (group A; Table 2; Fig. 4) may reflect autocrystic zircon growth, interpreted as dating the youngest magmatic episode.

The irregular, strongly luminescent boundary, dividing these two domains marks a change in conditions of crystallization involving zircon dissolution, followed by later magmatic crystallization, marked by weakly luminescent, oscillatory zoned rims (group A). Similarity of zircon internal structure to that described from mafic microgranular enclaves (Gawęda, 2009) accompanied by corroded crystal outlines suggest the zircon rims could represent the episode of hot, mantle-derived magma influx. Thus, resorption surfaces are likely to be related to magma mingling/mixing events.

Zircon crystals from CS sample revealed the presence of the inherited cores, surrounded by the rims, showing oscillatory growth zoning and weak luminescence, similar to WM sample. Based on the presence of magmatic zonation in the analysed crystals the concordia age of 


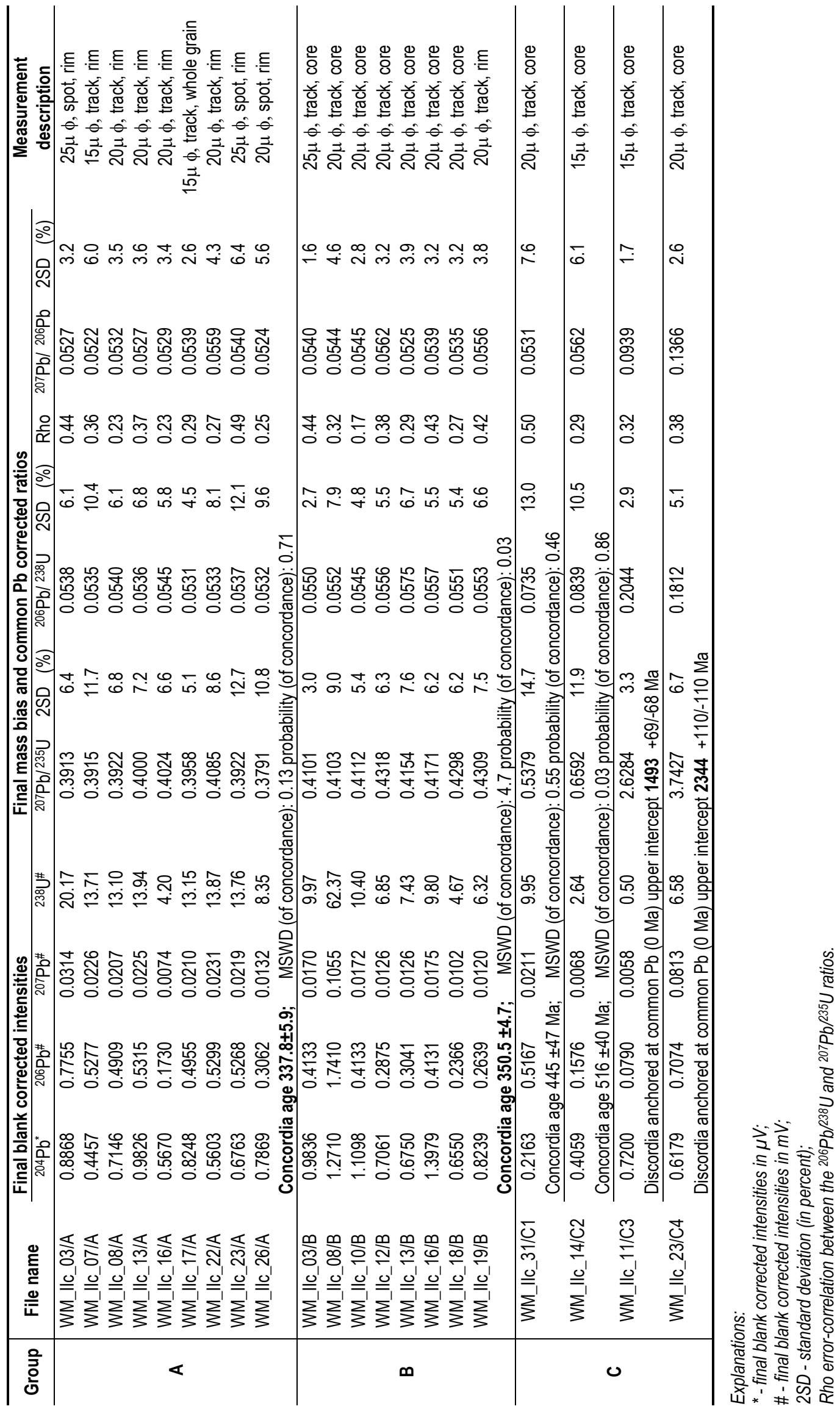




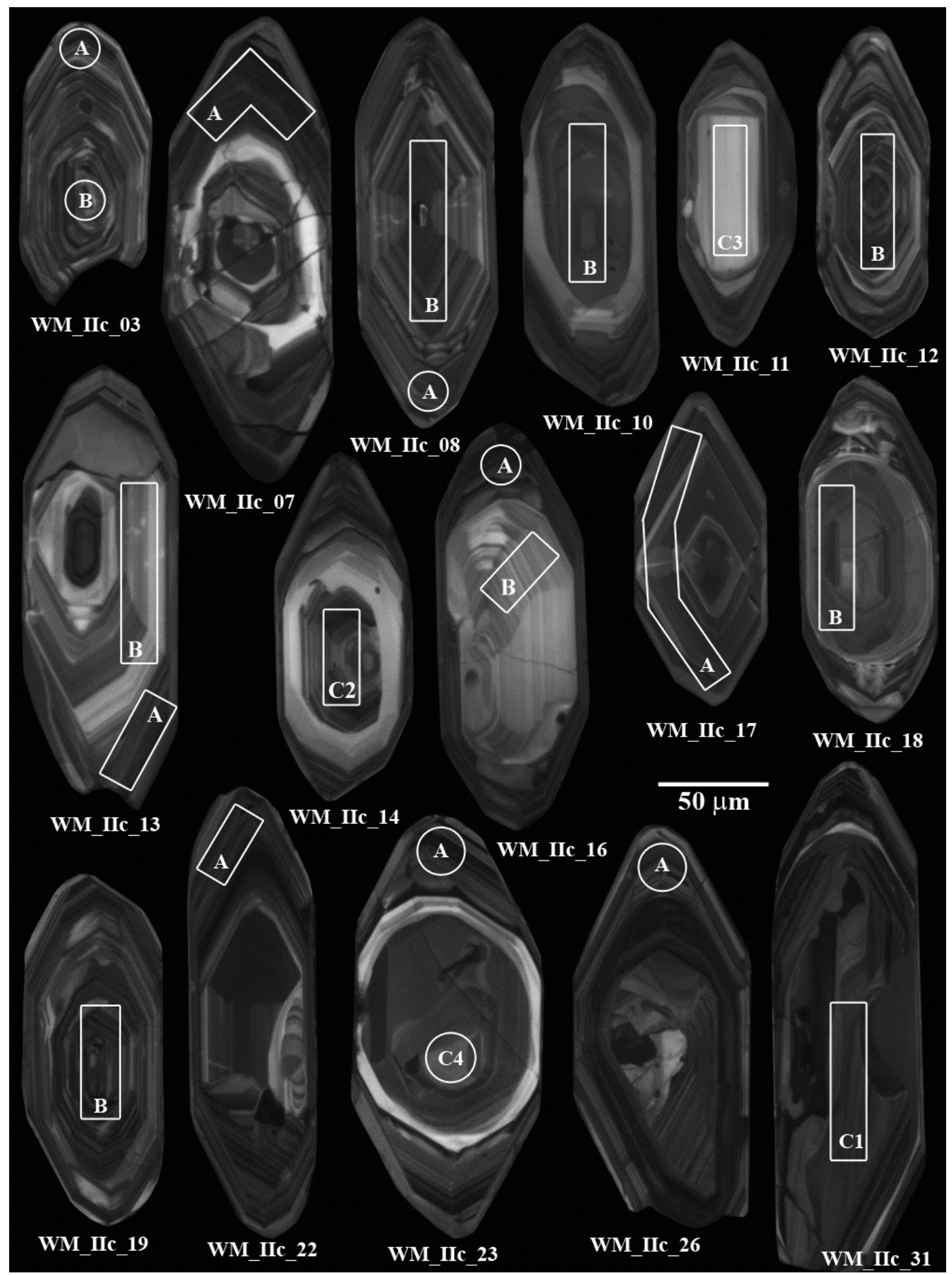

Fig. 4. Cathodoluminescence images of sections through zircon crystals from sample WM. See text for description. The white rectangles and circles show the approximate location of laser ablation trenches. 

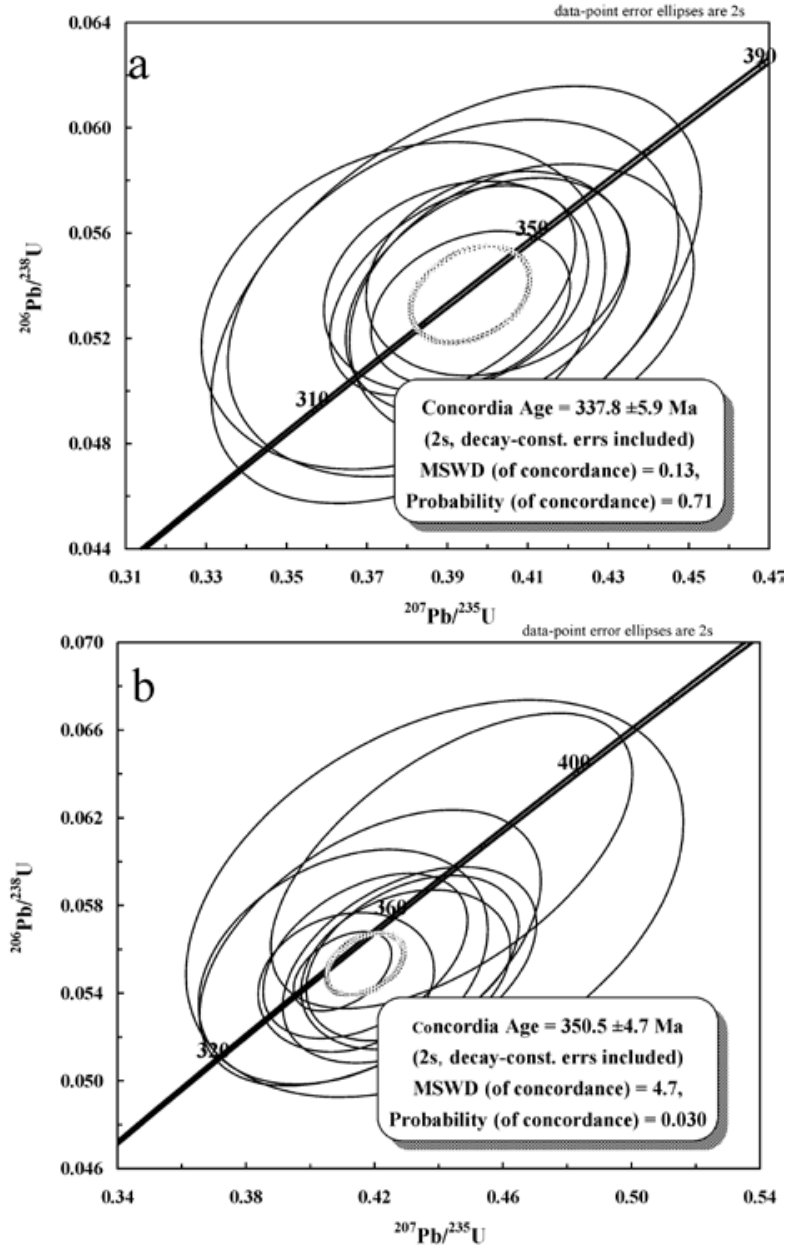

Fig. 5. Concordia plots of LA-MC-ICP-MS U-Pb zircon analytical results from sample WM. Open error ellipses are isotope ratios of individual grain spots on marginal rims (a) and internal domains (b). Thick error ellipse correspond to the $2 \sigma$ errors of the calculated concordia ages.

$345 \pm 6 \mathrm{Ma}$ ( 2 sigma) is considered to represent the crystallization age of this granite. The inherited material could be interpreted as an effect of enclaves/xenoliths recycling (compare Gawęda, 2008, Gawęda, 2009).

The published geochronological data located the youngest age of magmatic activity in the High Tatra granites at $314 \mathrm{Ma}$ on the base on U-Pb lower intercept age (Poller et al., 2000 and later discussion and interpretation in Poller et al., 2001). Data presented here do not support such a young U-Pb age. In contradiction, the zircon rims reflect the magmatic episode, placed at 330$345 \mathrm{Ma}$ (Figs. 5, 8), being in agreement with the $345 \mathrm{Ma}$ age suggested by Gawęda (2008) and $335 \mathrm{Ma}$, suggested by Burda (2010). Ages of inherited zircon cores are also in agreement with the formerly published data set (380-

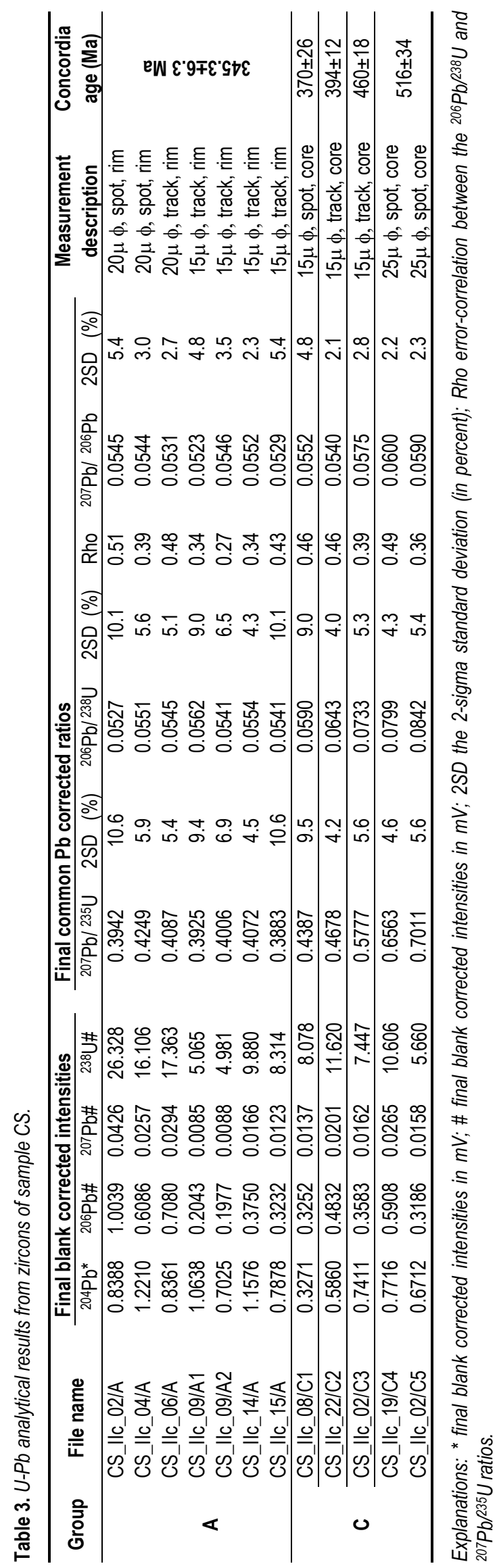




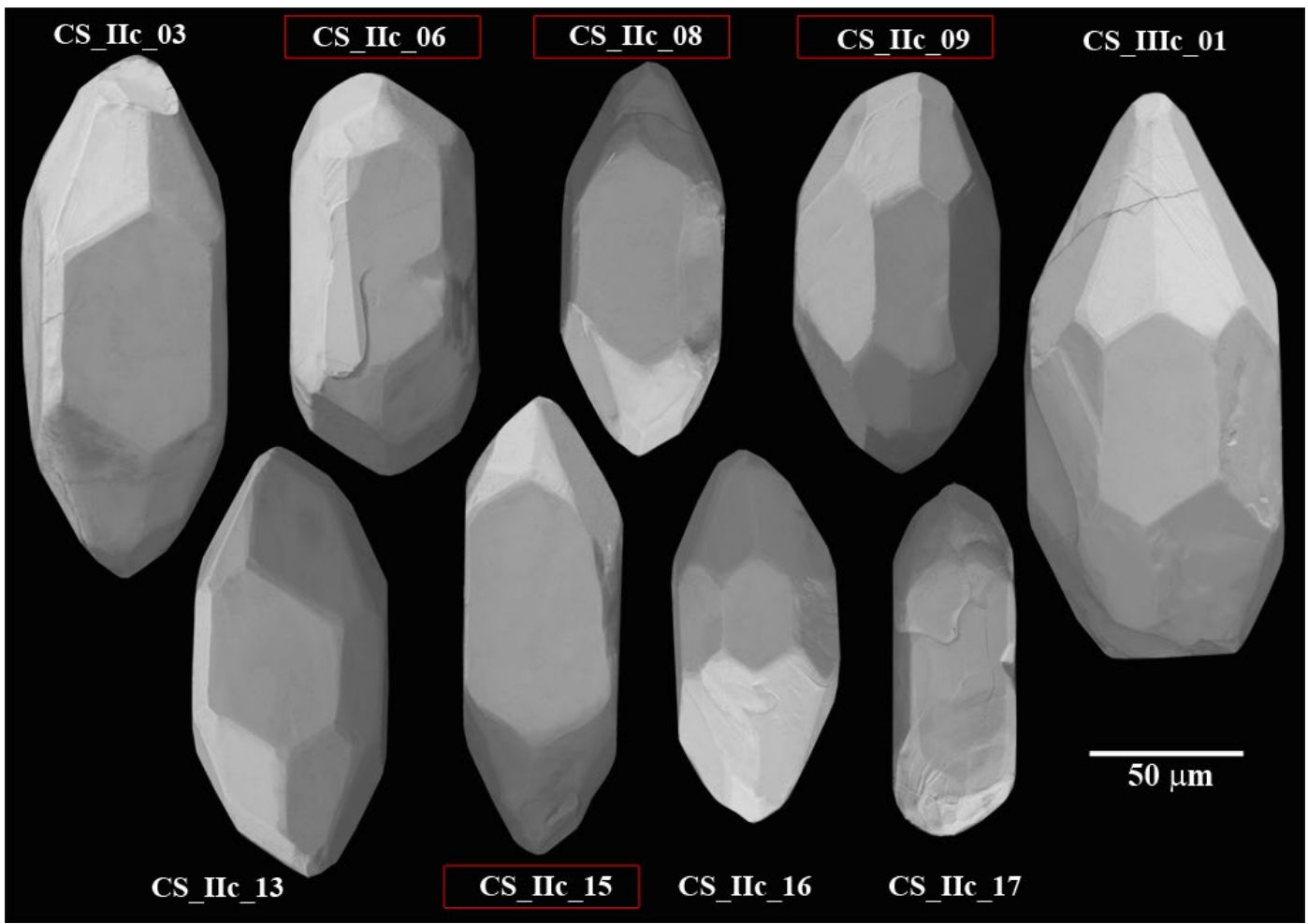

Fig. 6. Secondary electron (SEM) images of zircon crystals from sample CS. Zircon crystals are characterized by dominant [100] and [101] prisms and [211] pyramid. For the marked crystals by boxes cathodoluminescence images are presented in the Fig. 7.

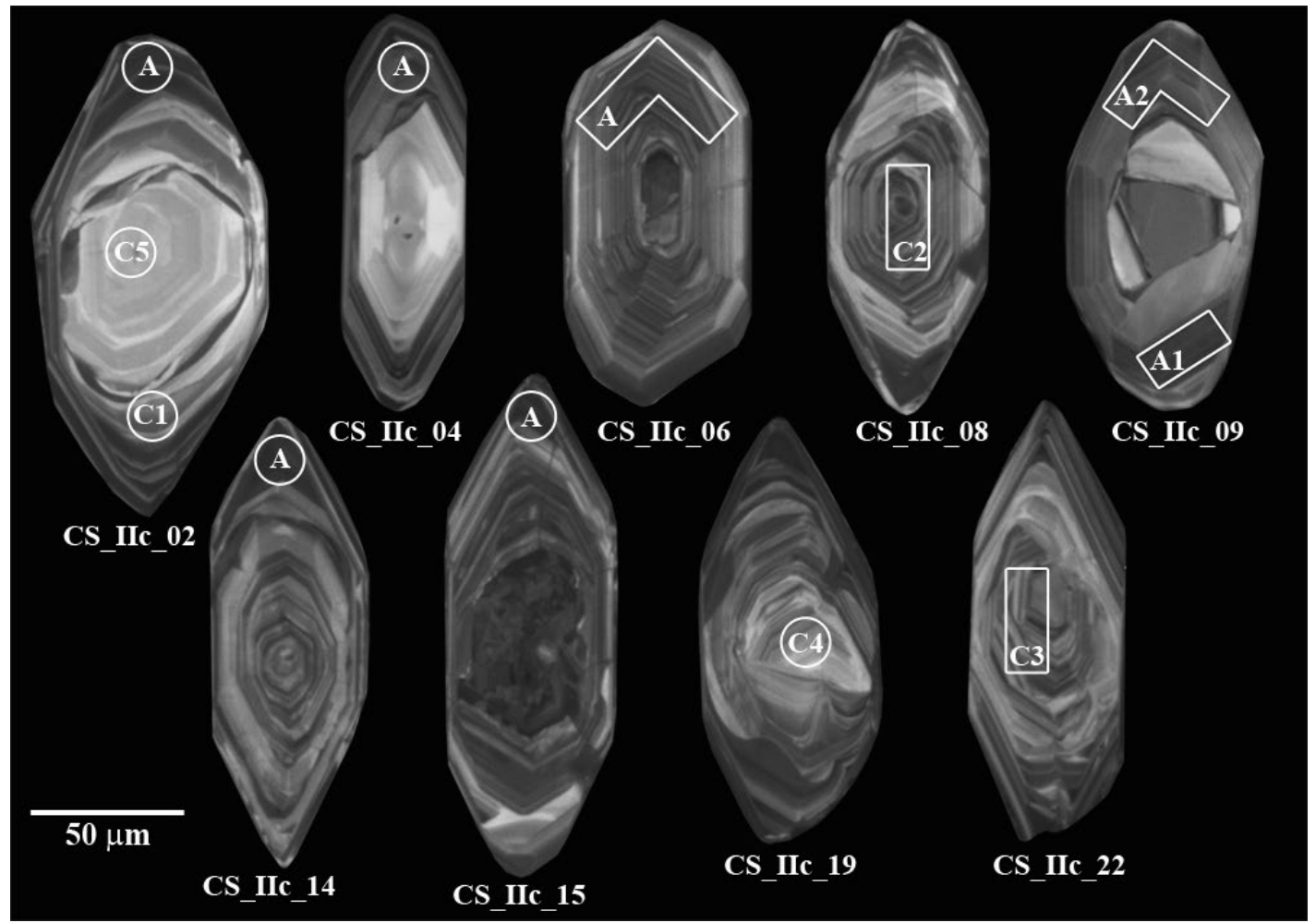

Fig. 7. Cathodoluminescence images of characteristic zircon populations from sample WM. See text for description. The white rectangles and circles show the approximate location of laser ablation trenches. 


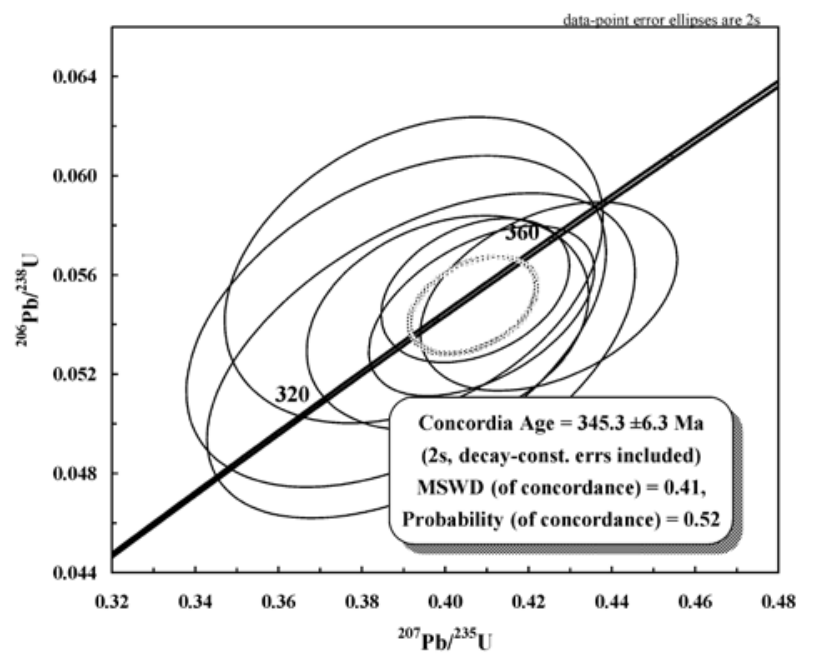

Fig. 8. Concordia plots of LA-MC-ICP-MS U-Pb zircon analytical results from sample CS. Open error ellipses indicate individual spot analysis from oscillatory zoning. Thick error ellipse corresponds to the $2 \sigma$ errors of the calculated concordia ages.

$390 \mathrm{Ma}, 450 \mathrm{Ma}, 516-530 \mathrm{Ma}, 1500 \mathrm{Ma}$ and ca. 2350 Ma; Gawęda, 2008, Burda and Klötzli 2011).

On the other hand, the age $314 \mathrm{Ma}$ (Poller et al., 2000) is similar (within brackets) to Rb-Sr cooling age 312 Ma from High Tatra Mountains (Gawęda, 2008), muscovite K-Ar ages 298-317 Ma from Western Tatra Mountains mylonites (Deditius, 2004) and biotite $\mathrm{Ar}-\mathrm{Ar}$ cooling ages placed at 330-300 Ma (Janak, 1994). These ages marked the long-lasting brittle-ductile shearing episode, post-dating the uplift and granitoid intrusion (Gawęda, 2009). Possibly the lower intercept, obtained by Poller et al. (2000) is a result of Pb loss from zircon, caused by that tectonic episode.

The presence of two magmatic episodes inside the High Tatra granite pluton (350-345 Ma and ca. $335 \mathrm{Ma}$ ) with significant input from the mantle sources allow to make some analogies to the granites from Bohemian Massif (e.g. Rastenberg granodiorite; Klötzli and Parrish, 1996). That makes possible to correlate the Variscan magmatic events in the Carpathians with the Central European Variscan Belt.

\section{CONCLUSIONS}

1) U-Pb zircon dating coupled with their internal structure analysis suggest the magmatic episode forming the High Tatra granitoid body in bracketed by $350-$ $337 \mathrm{Ma}$ with a maximum at $345 \mathrm{Ma}$. That relatively long time span is a result of prolonged collision processes and is in agreement with the layered character of the pluton.
2) The youngest magmatic episode is dated at $337 \mathrm{Ma}$ and related to a hot, possibly mantle-related magma influx.

3) U-Pb discordia age at $314 \mathrm{Ma}$ cannot be interpreted as an age of the magmatic event, but rather as an age of hydrothermal mobilization and associated $\mathrm{Pb}$ loss due to postmagmatic shearing.

\section{ACKNOWLEDGEMENTS}

The Polish Ministry of Sciences and Higher Education sponsored the investigations, by MNiSW grant No. 2 P04D 00329 (given to JB) and MNiSW grant No. N 307 027837 (given to AG). Additional funds from Austrian Science Fund FWF (START project 267-N11 and project P18202-N10 given to UK) is deeply acknowledged. Ewa Teper MSc is thanked for the assistance during CL investigations. Comments provided by the journal reviewer Milan Kohút and one anonymous reviewer are gratefully acknowledged.

\section{REFERENCES}

Broska I and Uher P, 2001. Whole-rock chemistry and genetic typology of the West-Carpathian Variscan granites. Geologia Carpathica 52: 79-90.

Burchart J, 1970. Skały krystaliczne wyspy Goryczkowej w Tatrach (Rocks of the Goryczkowa "crystalline island" in the Tatra Mountains.). Studia Geologica Polonica 32: 7-183 (in Polish).

Burda J, 2006. U-Pb zircon age of partial melting in metapelites from the Western Tatra Mts. Mineralogia Polonica - Special Papers, 29: 111-114.

Burda J, 2010. Internal structures and dating of complex zircons from High Tatra massif granodiorites, Poland. $10^{\text {th }}$ International conference-Methods of absolute chronology-22-25 April Gliwice, Poland. Abstracts \& Programme: 79.

Burda J and Klötzli U, 2007. LA-MC-ICP-MS U-Pb zircon geochronology of the Goryczkowa type granite - Tatra Mts., Poland. Mineralogia Polonica - Special Papers 31: 89-92.

Burda J and Gawęda A, 2009. Shear-influenced partial melting in the Western Tatra metamorphic complex: geochemistry and geochronology. Lithos 110: 373-385.

Burda J and Klötzli U, 2011. Pre-Variscan evolution of the Western Tatra Mountains: new insights from U-Pb zircon dating. Mineralogy and Petrology 102: 99-115.

Burda J, Gawęda A and Klötzli U, 2011. Magma hybridization in the Western Tatra Mountains granitoid intrusion (S-Poland, Western Carpathians). Mineralogy and Petrology 103: 19-36.

Deditius A, 2004. Charakterystyka i wiek izotopowy blastezy muskowitów ze stref mylonitycznych w skałach krystalicznych Tatr Zachodnich (Petrology and izotopic age of the muscovite blasthesis from the mylonitic zones in the crystalline rocks of the Western Tatra Mountains). Geologia 16. Wydawnictwo Uniwersytetu Śląskiego (in Polish, English abstract).

Gawęda A, 2008. Apatite-rich enclave in the High Tatra granite, Western Carpathians: petrological and geochronological study. Geologia Carpathica 59(4): 295-306.

Gawęda A, 2009. Enclaves in the High Tatra Granite. University of Silesia publishing House. Monographic series 2637, Katowice: 180 pages (in Polish, English abstract).

Gawęda A, Doniecki T, Burda J and Kohut M, 2005. The petrogenesis of quartz-diorites from the Tatra Mountains (Central Western Carpathians): an example of magma hybridisation. Neues Jahrbuch für Mineralogie-Abhandlungen 1: 95-109. 
Gawęda A and Sikorska M, 2009. Alkali feldspar megacrysts from the High Tatra granite - indicators of magma mixing/mingling processes. Mineralogia - Special Papers 35: 82.

Gaweda A and Szopa K, 2011. The origin of magmatic layering in the High Tatra granite, Central Western Carpathians - implications for the formation of granitoid plutons. Earth and Environmental Science Transactions of the Royal Society of Edinburgh 103: 129144.

Gawęda A and Włodyka R, 2013. The origin of post-magmatic Ca-Al minerals in granite-diorite mingling zones: The Tatra granitoid intrusion, Western Carpathians. Neues Jahrbuch für MineralogieAbhandlungen (in print).

Grabowski J and Gawęda A, 1999. Preliminary paleomagnetic study of the High Tatra granites, Central Western Carpathians, Poland. Geological Quaterly 43(3): 263-276.

Hildreth W, 2004. Volcanological perspectives on Long Valley, Mammoth Mountain, and Mono Craters: several contiguous but discrete systems. Journal of Volcanology and Geothermal Research 136(34): 169-198, DOI 10.1016/j.jvolgeores.2004.05.019.

Janak M, 1994. Variscan uplift of the crystalline basement, Tatra Mts., Central Western Carpathians: evidence from ${ }^{40} \mathrm{Ar} /{ }^{39} \mathrm{Ar}$ laser probe dating of biotite and P-T-t paths. Geologica Carpathica 45(5): 293-300.

Klötzli U and Parrish RR, 1996. Zircon $\mathrm{U} / \mathrm{Pb}$ and $\mathrm{Pb} / \mathrm{Pb}$ geochronology of the Rastenberg granodiorite, South Bohemian Massif, Austria. Mineralogy and Petrology 58: 197-214.

Kohút M and Janak M, 1994. Granitoids of the Tatra Mts., Western Carpathians: Field relations and petrogenetic implications. Geologica Carpathica 45(5): 301-311.

Kohút M and Nabelek PI, 2008. Geochemical and isotopic (Sr, Nd and O) constraints on sources of Variscan granites in the Western Carpathians - implications for crustal structure and tectonics. Journal of Geosciences 53: 307-322, DOI 10.3190/jgeosci.033.

Kohút $\mathrm{M}$ and Sherlock S, 2003. Laser microprobe ${ }^{40} \mathrm{Ar}^{39} \mathrm{Ar}$ analysis of pseudotachylyte and host rocks from the Tatra Mountains, Slovakia: Evidence for Late Paleogene seismic/tectonic activity. Terra Nova 15(6): 417-424, DOI 10.1046/j.1365-3121.2003.00514.x.

Leichmann, J, Jacher-Sliwczynska K and Broska I, 2009. Element mobility and fluid path ways during feldspar alteration: textural evidence from cathodoluminescence and electron microprobe study of an example from tonalites (High Tatra, PolandSlowakia). Neues Jahrbuch für Mineralogie-Abhandlungen 186(1): 1-10.

Ludwig KR, 2003. Isoplot/Ex version 3.00. A geochronological toolkit for Microsoft Excel. Berkeley Geochronology Center. Special Publication 4: 1-74.

Morozewicz K, 1914. Über die Tatragranite (About the Tatra granite). Neues Jahrbuch für Geologie und Palaontologie-Abhandlungen 39: 289-345.

Poller U, Janak M, Kohút M and Todt W, 2000. Early Variscan magmatism in the Western Carpathians: U-Pb zircon data from granitoids and orthogneisses of the Tatra Mountains (Slovakia). International Journal of Earth Sciences 89(2): 336-349, DOI $10.1007 / \mathrm{s} 005310000082$

Poller $\mathrm{U}$ and Todt $\mathrm{W}, 2000$. U-Pb single zircon data of granitoids from the High Tatra Mountains (Slovakia): implications for the geodynamic evolution. Transactions of the Royal Society of Edinburgh: Earth and Environmental Science 91: 235-243.

Poller U, Todt W, Kohút M and Janak M, 2001. Nd, Sr, Pb isotope study of the Western Carpathians: implications for the Paleozoic evolution. Schweizerische Mineralogische und Petrographische Mitteilungen 81: 159-174.

Pupin JP, 1980. Zircon and granite petrology. Contribution to Mineralogy and Petrology 73: 207-220.

Sláma J, Kosler J, Schaltegger U, Tubrett M and Gutjahr M, 2006. New natural zircon standard for laser ablation ICP-MS U-Pb geochronology. Abstract WP05. Winter Conference on Plasma Spectrochemistry, Tucson: 187-188.

Stacey JS and Kramers JD, 1975. Approximation of terrestrial lead isotope evolution by a two stage model. Earth and Planetary Science Letters 26(2): 207-221, DOI 10.1016/0012-821X(75)90088-

Sun SS and McDonough WF, 1989. Chemical and isotopical systematics of oceanic basalts: implications for mantle composition and processes. Magmatism in the Oceanic Basins. Geological Society London Special Publications 42: 313-345.

Sylvester PJ and Ghaderi M, 1997. Trace element analysis of scheelite by excimer laser ablation-inductively coupled plasma-mass spectrometry (ELA-ICP-MS) using a synthetic silicate glass standard. Chemical Geology 141(1-2): 49-65, DOI 10.1016/S00092541(97)00057-0.

Watson TM and Harrison EB, 1983. Zircon saturation revisited: temperature and composition effects in a variety of crustal magma types. Earth and Planetary Science Letters 64(2): 295-304, DOI 10.1016/0012-821X(83)90211-X.

Wiedenbeck M, Alle P, Corfu F, Griffin WL, Meier M, Oberli F, Von Quadt A, Roddick JC and Spiegel W, 1995. Three natural zircon standards for U-Th- $\mathrm{Pb}$, Lu-Hf, trace element and REE analyses. Geostandards Newsletter 19: 1-23. 